\title{
SOLAR RESOURCE MAPPING IN THE VALE SÃO FRANCISCO DA BAHIA USING THE WRF-SOLAR MODEL
}

\author{
Carolina Sacramento Vieira ${ }^{a}$, Anderson da Silva Palmeira ${ }^{a}$, Palmira Maria Acioli \\ Dias $^{a}$, Erick Giovani Sperandio Nascimento ${ }^{a}$, Davidson Martins Moreira ${ }^{a}$ \\ a Centro Universitário Senai Cimatec
}

\begin{abstract}
To assist the planning of the electrical system with reliable information on the temporal variability of solar irradiation and consequently efficient use of this source, the present work aims to estimate and map solar radiation in the micro-region of Barra, located in the Vale São Francisco of the Bahia, using the numerical model WRF-Solar. The period of the simulations was the months of January and July 2019, a period in which the days of perihelion (3th January) and aphelion (4th July) occur. The simulations were satisfactory through statistical analysis between simulated and observed data, with a normalized quadratic error of 0.08 and 0.13 , a factor of two of 0.81 and 0.76 , and a correlation coefficient of 0.90 and 0.76 , respectively, for the months of January and July. Therefore, the computational tool has good forecasting capabilities, with great potential for operational, research, and technological development purposes.
\end{abstract}

Keywords: solar radiation; Vale São Francisco of the Bahia; WRF-Solar.

\section{MAPEAMENTO DO RECURSO SOLAR NO VALE SÃO FRANCISCO DA BAHIA UTILIZANDO O MODELO WRF-SOLAR}

Resumo: Com o intuito de auxiliar o planejamento do sistema elétrico com informações confiáveis sobre a variabilidade temporal da irradiação solar e, consequentemente, o uso eficiente desta fonte, o presente trabalho tem por objetivo estimar e mapear a radiação solar na microrregião da Barra, localizada no Vale São Francisco da Bahia, utilizando o modelo numérico WRF-Solar. O período das simulações foram os meses de janeiro e julho de 2019 , período em que ocorre os dias de periélio (03/01) e afélio (04/07). As simulações mostraram-se satisfatórias através de análises estatísticas entre dados simulados e observados, com um erro quadrático normalizado de 0,08 e 0,13, fator de dois de 0,81 e 0,76 e coeficiente de correlação de 0,90 e 0,76, respectivamente, para os meses de janeiro e julho. Portanto, a ferramenta computacional apresenta boa capacidade de previsão, com grande potencial para fins operacionais, de pesquisa e desenvolvimento tecnológico.

Palavras-chave: radiação solar; Vale São Francisco da Bahia; WRF-Solar. 


\section{INTRODUCTION}

The electric matrix in Brazil contemplates of way exemplary to use renewable energy. According to the Ministry of Mines and Energy (2020), participation led by the hydroelectric plant $(63.8 \%)$, followed by wind $(9.3 \%)$, biomass $(8.9 \%)$, and centralized solar $(1.4 \%)$. However, the increased demand for energy, coupled with the growing concern for the environment, is driving a scientific community to research and develop alternative sources of renewable energy that minimize the degradation of the planet's natural resources and add security to energy use in times of drought. Renewable solar and wind energy represent an important option to diversify energy sources to meet the growing global demand for energy [1].

In Brazil, the solar source already presents, along with wind energy, as one of the most promising ways of expanding the electric generator park. Solar energy in Brazil has made great progress as of 2016, due to improvements in the legal framework for distributed generation and mainly due to the reduction in the price of photovoltaic modules. From 2016 to 2019 , the capacity of solar photovoltaic generation in Brazil reached 4.5 GW, of which $2.5 \mathrm{GW}$ in centralized projects and $2.0 \mathrm{GW}$ in distributed generation [2].

According to the second edition of the Brazilian Atlas of Solar Energy (2017), the Northeast region of Brazil has the best parameters, particularly its semiarid portion. In this region, stands out Bahia, according to data from the National Electric Energy Agency (ANEEL), created and controls the centralized generation segment in Brazil, Bahia is a leader in the generation of solar energy with $25 \%$ of the solar parks in Brazil. Brazil. The high levels of solar radiation are one of the outstanding factors in the generation of energy in Bahia, totaling 777 Megawatts (MW) of capacity until the end of January 2020. The large solar photovoltaic plants aggregated $551 \mathrm{MW}$ to the Brazilian matrix [3].

However, for the development of solar projects, the reference magnitudes are essential for the characterization of the existing solar resource, since the radiation reaches the variable terrestrial surface, due to its intermittent and seasonal characteristics. The distance between the Earth and the Sun varies throughout the year, its average distance is $1,496.10^{8} \mathrm{~km}$ Iso changes; known as Astronomical Unit, according to [4], it can vary during the period when the soil is closest to the Sun (perihelion) from $1,47.10^{8} \mathrm{~km}$ to $1,52.10^{8} \mathrm{~km}$ (aphelion). This differentiation of the EarthSun distance and seasonal positioning of the Earth in the elliptical plane directly affects the average balance of the incident radiation [5].

Therefore, in order to assist or plan the operation of the country's electrical system, especially in the case of photovoltaic plants, studies are needed to make it possible to know its regional availability, temporal variability, and predictability [6]. Numerical weather prediction models (NWP) have been used to forecast meteorological variables that solve physical processes from a surface until the high atmosphere. NWPs are classified into two categories: models that operate on a global scale, such as the NOAA GFS (USA) or the European Center's ECMWF, and models on a regional scale, such as WRF (Weather Research and Forecasting). The atmospheric WRF-Solar model, object of this work, is an extension and specific configuration of the WRF model with the objective of providing an improved numerical tool for specific research and applications in the solar energy sector. The model is based on the WRF modeling framework and was developed through a project funded 
by the Department of Energy (DOE - USA) that seeks improvements on forecasts in global horizontal and normal direct irradiation.

The enhancements introduced in WRF to create WRF-Solar focus on improving the representation of the cloud-aerosol-radiation system. the new configurations use a new aerosol parameterization that allows providing accurate quantification of the aerosol attenuation, the interaction with cloud microphysics, and a radiative fast transfer algorithm that allows estimating the solar irradiance with high temporality and low temporal cost. Many studies have already highlighted the benefits of these improvements in the model for solar forecasting [7].

The performance of the WRF model evaluated for the solar irradiation forecast has become an active research field in recent years. In Brazil, the estimate of solar energy by NWP models is in the stage of development and diagnosis. Within this context, the objective of this work is to estimate and map solar radiation in the microregion of Barra located in the São Francisco da Bahia Valley, using the WRF-Solar model. The period of the simulations was carried out in the months of January and July 2019. To validate the capacity of the WRF-Solar, the data simulated by the model are compared with the data collected by the INMET (National Institute of Meteorology) automatic stations located in the micro-regions of the Vale São Francisco. The mapping of the solar resource was performed with the ArcGIS Pro Software, using the WRF-Solar output files in the days of aphelion and perihelion.

\section{METHODOLOGY}

\subsection{Study area description}

The São Francisco River basin is one of the largest hydrographic basins in Brazil, it integrates and connects the Brazilian Sertão with other regions of the country. The area of study of the present work corresponds to a specific part of the Basin, the region of the São Francisco da Bahia Valley (Figure 1), characterized by an urban, industrial, and predominantly agricultural region. The São Francisco Baiano Valley is located in the northeastern semiarid, between latitudes $8^{\circ} 50^{\prime}$ and $14^{\circ} 70^{\prime}$ and longitudes $38^{\circ} \mathrm{O}$ and $44^{\circ} 50^{\prime} \mathrm{O}$; it has a total area of $109,891.6 \mathrm{~km}^{2}$ and an estimated population of 1.001.568 inhabitants [8]. It consists of four microregions, these are Paulo Afonso, Juazeiro, Barra, and Bom Jesus da Lapa. In addition to activities related to agriculture and commerce, it is also located in this region the main hydroelectric power plants that represent the energy supply base of the Northeast [9]. The Atlas Solar da Bahia (2018) recorded the predominance of solar incidence in the region along the São Francisco River Valley, which is the most privileged in Bahia. The average hourly radiation varies approximately between 700 to $1,100 \mathrm{Wh} / \mathrm{m}^{2}$, which shows the potential promising of the region in solar energy harnessing.

Next, Figure 1 details the location of the Vale São Francisco of the Bahia and its 4 microregions. 
Figure 1. Vale São Franciscano of the Bahia

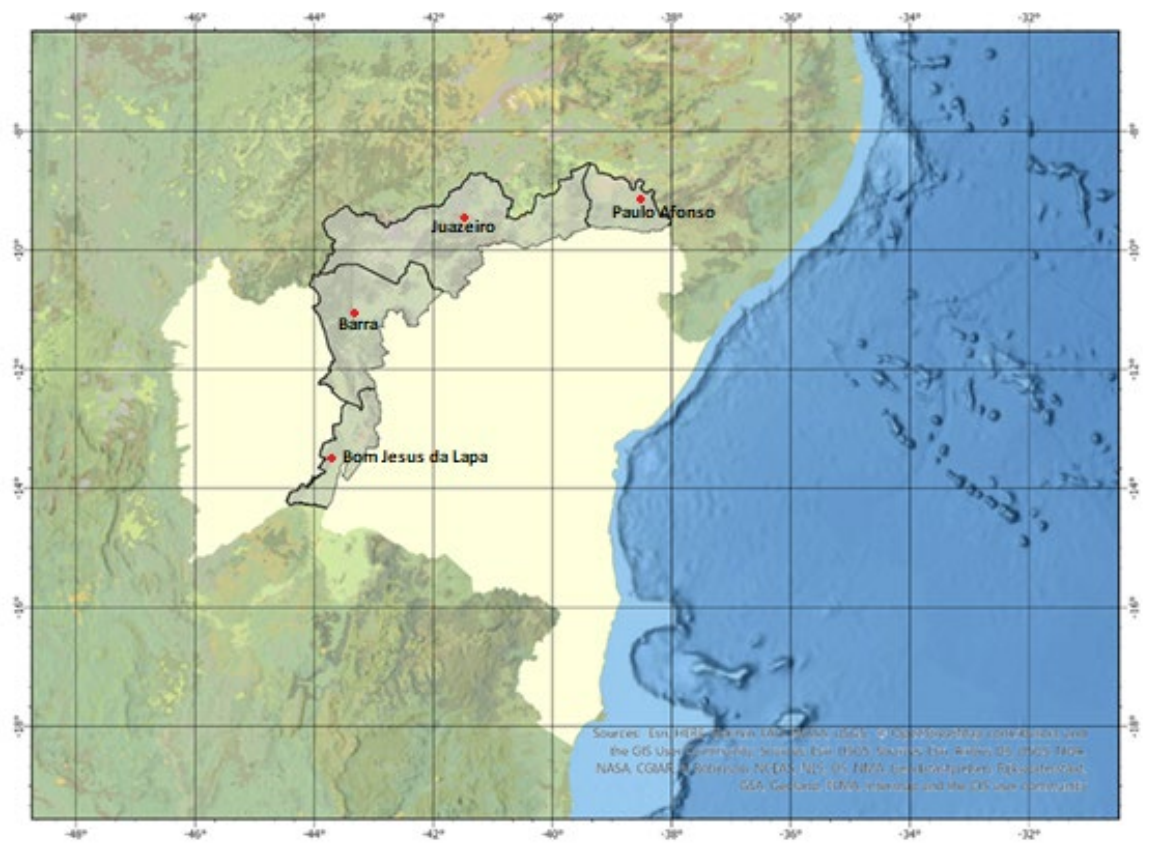

Source: Author (2020).

\subsection{WRF-Solar simulation details}

The simulations were held using a specific configuration in the WRF model, suitable for solar meteorological forecast, called WRF-Solar version 1.2.0 with starting at 0000 UTC extending until 1800 UTC in the months of January and July for the microregion under study. The first 24 hours of simulations were used as a "spin-up", which is the model adjustment time and were excluded from the assessments. The initial and boundary conditions employed in the simulations are from the global atmospheric model GFS (Global Forecast System) of the NCEP (National Center for Environmental Prediction), with a horizontal resolution of $0.25^{\circ} \times 0.25^{\circ}$ and temporal resolution of 6 hours. Topography and land use and occupation data are defined by the USGS (United States Geological Survey) with a resolution of 5 ', 2', and 30s. The time period analyzed was January and July 01th to 30th 2019.

The model was run with three nested domains with grid resolutions of $9 \mathrm{~km}, 3$ $\mathrm{km}$ and $1 \mathrm{~km}$, respectively (Fig. 2). The domain of interest has horizontal resolution of $1 \mathrm{~km}$ and thirty-five vertical levels with the model top set at $50 \mathrm{hPa}$. An overview of spatial configurations is shown in Table 1.

Table 1. Details of the model configuration

\begin{tabular}{|c|c|c|c|c|c|}
\hline \multirow{3}{*}{ Region } & Domain & $\begin{array}{c}\text { Horizontal } \\
\text { resolution }\end{array}$ & $\begin{array}{c}\text { Domain } \\
\text { size (km) }\end{array}$ & $\begin{array}{c}\text { Cell } \\
\text { numbers }\end{array}$ & $\begin{array}{c}\text { Number of } \\
\text { levels } \boldsymbol{~}\end{array}$ \\
\hline \multirow{3}{*}{ Barra } & $\mathrm{D} 01$ & $9 \mathrm{~km}$ & $351 \times 351$ & $39 \times 39$ & \multirow{2}{*}{35} \\
\cline { 2 - 5 } & $\mathrm{D} 02$ & $3 \mathrm{~km}$ & $189 \times 189$ & $63 \times 63$ & \\
\cline { 2 - 5 } & $\mathrm{D} 03$ & $1 \mathrm{~km}$ & $139 \times 139$ & $139 \times 139$ & \\
\hline
\end{tabular}


Figure 2. Location of the three nested domains in microregion of the Barra

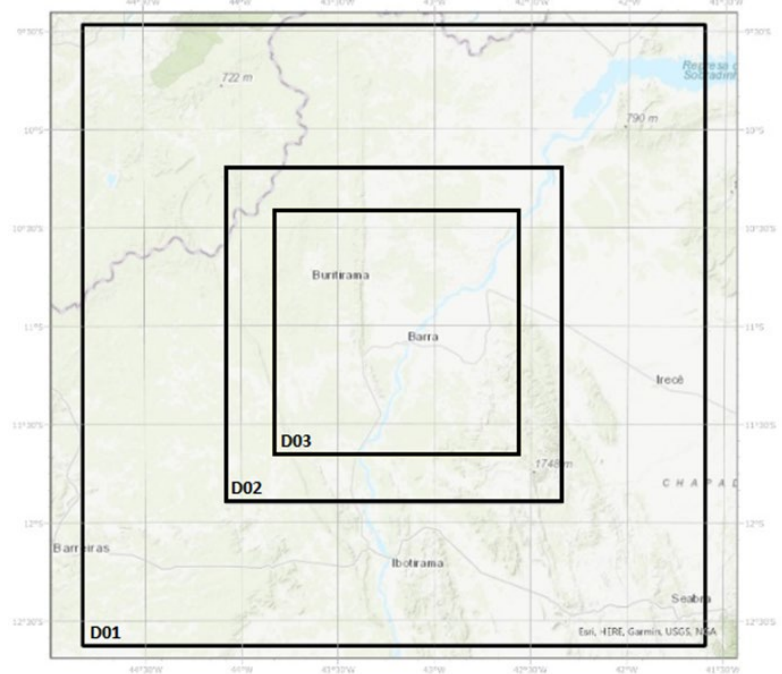

Source: Author (2020).

The physics options adopted and, left unchanged for all simulations, were: Thompson aerosol-aware microphysics, cumulus Grell 3D, Planetary boundary layer parameterization (PBL) (Eta similarity and Mellor-Yamada-Janjic), RRTMG short wave radiation, longwave radiation RRTMG, and Noah land-surface model. In the second and third domains which were run at $3 \mathrm{~km}$ and $1 \mathrm{~km}$ spatial resolution, respectively, simulations were carried out using explicit convection, following the model's indications of not using convection schemes for domains below $10 \mathrm{~km}$ of spatial resolution. The parameterization of aerosol interactions with radiation follows Ruiz-Arias et al. (2014). Activating this option allows considering constant values of aerosols in the RRTMG radiation scheme.

After simulating data from the WRF-Solar model for the period under study, the data were post-processed. To validate the forecast, hourly observational data from surface weather stations monitored by INMET were used.

\section{RESULTS AND DISCUSSION}

The performance of the WRF-Solar model was evaluated by comparing the simulated solar irradiation data with the data observed in the location of interest. Figure 3 illustrates the hourly behavior of solar irradiation for the analyzed period and compares the observed values with the model's results. 
Figure 3. Comparison of hourly behavior of simulated and observed solar irradiation
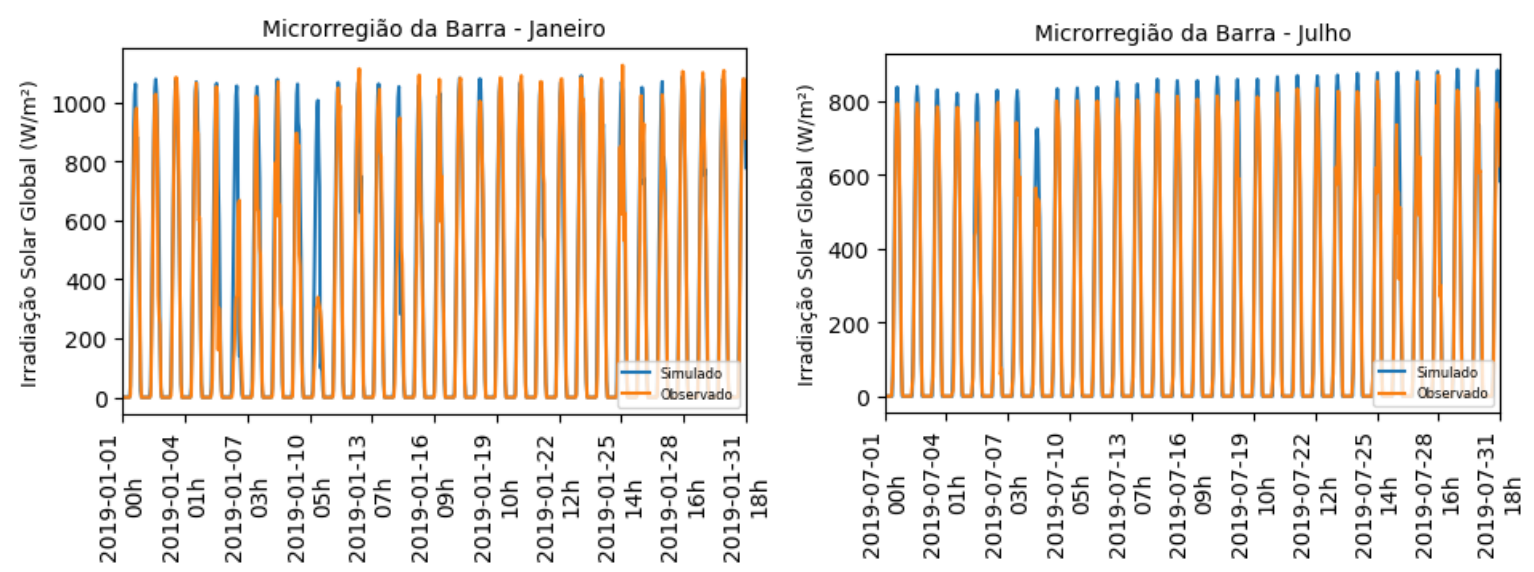

Note that for a large part of the period the model is able to follow the average hourly variation of the observed data. The month of January is characterized by higher radiation index than in the month of July. However, it is possible to observe a greater stability in the irradiation values in the month of July, this can be explained by the period of drought in the region (Jul-Sep-Oct-Nov) and in January 2019 there were rainfall days.

Analyzing the temporal spatial distribution of global irradiance in the region under study, the microregion of Barra presents the highest values: between 1000 and $1100 \mathrm{~W} / \mathrm{m}^{2}$ in January and, 750 to $800 \mathrm{~W} / \mathrm{m}^{2}$ in July.

In addition, a statistical evaluation was used, where in the indexes described the following (Eqs. 1, 2 and 3), o and p refer to the observed measures and simulated by the model, respectively. The bar indicates mean and " $\sigma$ " or standard deviation [10].

NMSE (Normalized Quadratic Error) $=\overline{\left(X_{o}-X_{p}\right)^{2}} / \overline{X_{p}} \overline{X_{o}}$,

FAT2 (Factor of two), fraction of data that are between $0.5 \leq\left(X_{p} / X_{o}\right) \leq 2$,

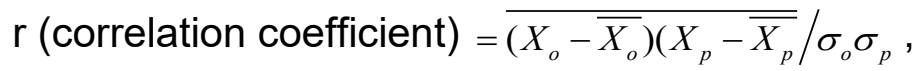

The best results are achieved when the NMSE values are close to zero (optimal value $=0$ ) and the FAT2 and $r$ values close to one (optimal value $=1$ ). Table 2 shows the statistical metrics calculated for the analysis of the model's performance.

Table 2. Statistical comparison between observed and simulated data

\begin{tabular}{ccccc}
\hline \multicolumn{5}{c}{ Microregion of Barra } \\
\hline Station & Month & NMSE & r & FAT2 \\
\hline \multirow{2}{*}{ Barra/BA } & Jan & 0,08 & 0,9 & 0,81 \\
\cline { 2 - 5 } & Jul & 0,13 & 0,76 & 0,76 \\
\hline
\end{tabular}

Figure 4 shows the scattering of simulated solar irradiation compared to the observed irradiation. 
Figure 4. Scatter plot of simulated and observed solar irradiation
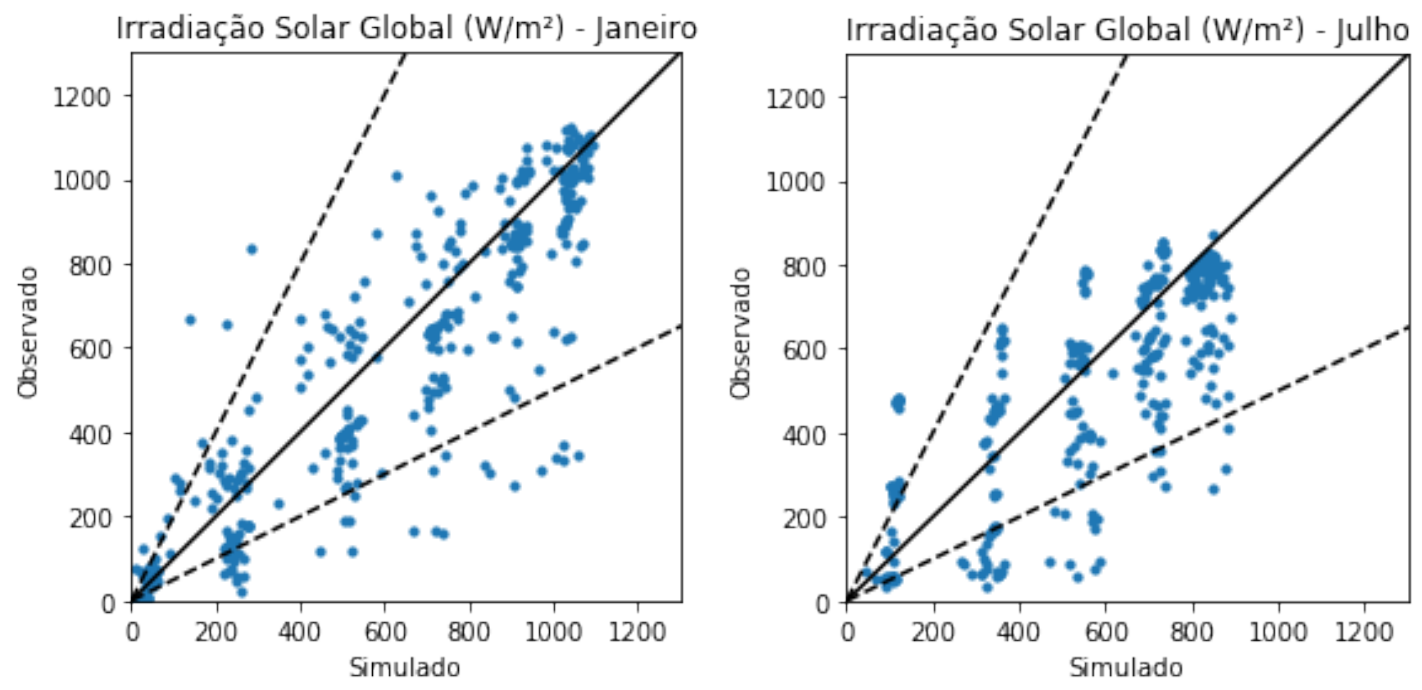

By analyzing the statistical indicators and Figure 4, it appears that the model tends to overestimate solar radiation in some points. However, the month of January performed better with a lower NMSE (0.08) and higher FAT2 (90\%) and r (81\%).

To spatially analyze the solar radiation outputs of the model, the analysis was performed on the days of aphelion (4th of July) and perihelion (3rd of January). One of the objectives that led to the choice these days was to evaluate solar radiation under the influence of the Earth-Sun distance. Next, Figure 5 illustrates the irradiation maps at the point of greatest and least distance Earth-Sun for the region under study.

Figure 5. Solar irradiation map on Periélio (left) and Afélio (right)
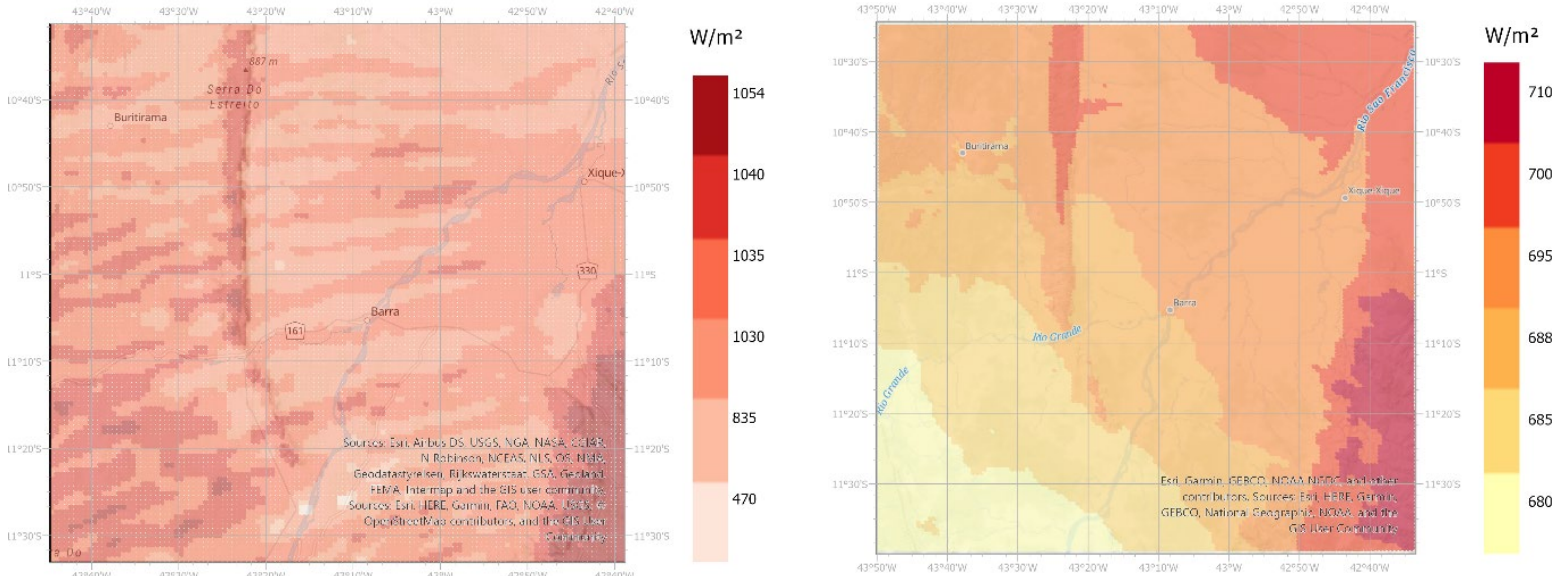

It is observed that, at 12 hours (local time), the highest irradiation value is equivalent to $1054 \mathrm{~W} / \mathrm{m}^{2}$ in perihelion and $710 \mathrm{~W} / \mathrm{m}^{2}$ in aphelion. In addition, note that the model get to capture this important physical difference in relation to the sun. 


\section{CONCLUSION}

The estimate of solar radiation, carried out by the atmospheric model WRFSolar, reached the objectives proposed in this work. Although the model overestimates solar radiation, the statistical indices showed good results. It is also observed that the correlation coefficients have good levels between simulations and observations, greater than 0.7 . The model was able to follow the trend of the measured data, which shows the model's ability to simulate solar irradiation in the region.

The model shows it to be an effective and important computational tool in carrying out surveys of this type, proving the methodology in the region. Despite being an initial assessment and only two months, this work will can to contributes to the decision making of the National Electric System Operator (ONS) in the analysis of the technical and economic feasibility for the implantation of solar plants in Brazil and, especially, in Bahia.

\section{Acknowledgments}

The authors thank the Supercomputing Center for Industrial Innovation (CIMETC HPC OGUN and Yemoja) for providing the computational infrastructure needed to run the models, and the Fundação de Amparo à Pesquisa do Estado da Bahia (FAPESB) for the financial support.

\section{REFERENCES}

1BEZERRA, F. D. Nordeste: Futuro Promissor para Energia Solar. In: Caderno Setorial ETENE, ano 3, n.31, 2018.

${ }^{2}$ BEZERRA, F. D. Energia Solar. In: Caderno Setorial ETENE, ano 5, n.110, 2020.

${ }^{3} A N E E L$ - AGÊNCIA NACIONAL DE ENERGIA ELÉTRICA. Sistema de Informações de Geração da ANEEL - SIGA. Available at:<http://www.annel.gov.br>. Acesso em: 02 jun. 2020.

${ }^{4}$ PEREIRA, E. B.; MARTINS, F. R.; GONÇALVES, André Rodrigues; COSTA, Rodrigo Santos; LIMA, F. J. L. de; RÜTHER, R.; ABREU, S. L. de; TIEPOLO, G. M.; PEREIRA, S. V.; SOUZA, J. G. de. Atlas brasileiro de energia solar. 2a. ed. São José dos Campos: INPE, 2017.

${ }^{5}$ CORREA, M. G. G.; GALVANI, E. Uma abordagem teórica das interações no Sistema Superfície-Atmosfera (SSA) na bacia do Rio Piquiri-PR. Revista Geonorte, Manaus, v. 1, n. 5, p. 1245-1255, 2012.

${ }^{6}$ LIMA, Francisco J.L. Solar radiation forecasting in northeast Brazil using the WRF model adjusted by artificial neural networks (ANN). Previsão de irradiação solar no Nordeste do Brasil empregando o modelo WRF ajustado por redes neurais artificiais (RNAs), São José dos Campos: INPE, 2015. 628p.

${ }^{7}$ JIMENEZ, P.A. et al. WRF-Solar: Description and Clear-Sky Assessment of an Augmented NWP Model for Solar Power Prediction. Bull. Amer. Met. Soc.. 97, 12491264. 
8INSTITUTO BRASILEIRO DE GEOGRAFIA E ESTATÍSTICA (IBGE). (2019) Banco de Dados - $\quad$ Cidades. Disponível em: <http://www.cidades.ibge.gov.br/v3/cidades/home-cidades>. Acesso em: 21 mai. 2020.

${ }^{9}$ AGÊNCIA NACIONAL DE ÁGUAS (ANA). São Francisco. Disponível em: < https://www.ana.gov.br/sala-de-situacao/sao-francisco>. Acesso em: 18 jun. 2020.

${ }^{10}$ HANNA, Steven. Confidence limit for air quality models as estimated by bootstrapand jacknife resampling methods. Atmos. Environ. 1989. 